\title{
Nota
}

\section{SOIL FERTILITY, NUTRITION AND YIELD OF MAIZE AND BARLEY WITH GYPSUM APPLICATION ON SOIL SURFACE IN NO-TILL ${ }^{(1)}$}

\author{
Leandro Michalovicz ${ }^{(2)}$, Marcelo Marques Lopes Müller ${ }^{(3)}$, José Salvador Simoneti Foloni ${ }^{(4)}$, \\ Jackson Kawakami $^{(3)}$, Ronaldo do Nascimento ${ }^{(5)}$ \& Luiz Fernando Machado Kramer ${ }^{(2)}$
}

\section{SUMMARY}

Annual crop yield and nutrition have shown differentiated responses to modifications in soil chemical properties brought about by gypsum application. The aim of this study was to evaluate the effect of gypsum application rates on the chemical properties of a Latossolo Bruno (Clayey Oxisol), as well as on the nutrition and yield of a maize-barley succession under no-till. The experiment was set up in November 2009 in Guarapuava, Parana, Brazil, applying gypsum rates of 0.0, 1.5, 3.0, 4.5, and 6.0 $\mathrm{Mg} \mathrm{ha}^{-1}$ to the soil surface upon sowing maize, with crop succession of barley. Gypsum application decreased the levels of $\mathrm{Al}^{3+}$ and $\mathrm{Mg}^{2+}$ in the $0.0-0.1 \mathrm{~m}$ layer and increased soil $\mathrm{pH}$ in the layers from 0.2-0.6 $\mathrm{m}$ depth. Gypsum application has increased the levels of $\mathrm{Ca}^{2+}$ in all soil layers up to $0.6 \mathrm{~m}$, and the levels of $\mathrm{S}_{-} \mathrm{SO}_{4}{ }^{2-}$ up to $0.8 \mathrm{~m}$. In both crops, the leaf concentrations of $\mathrm{Ca}$ and $\mathrm{S}$ were increased while $\mathrm{Mg}$ concentrations have decreased as a function of gypsum rates. There was also an effect of gypsum rates on grain yield, with a quadratic response of maize and a linear increase for barley. Yield increases were up to 11 and $12 \%$ in relation to control for the maximum technical efficiency (MTE) rates of 3.8 and $6.0 \mathrm{Mg} \mathrm{ha}^{-1}$ of gypsum, respectively. Gypsum application improved soil fertility in the profile, especially in the subsurface, as well as plant nutrition, increasing the yields of maize and barley.

Index terms: phosphogypsum, calcium saturation, sulfur, Zea mays, Hordeum vulgare.

(1) Part of the first author's Master Dissertation, presented in the Universidade Estadual do Centro-Oeste - UNICENTRO. Received for publication on October 30, 2013 and approved on June 11, 2014.

(2) Doctoral Student, Graduate Studies in Soil and Plant Nutrition, Universidade Estadual de Maringá. Av. Colombo, 5790. CEP 87020-900 Maringa (PR), Brazil. E-mail: leandromichalovicz@yahoo.com.br, luizfernandokramer@gmail.com

(3) Full Professor, Department of Agronomy, UNICENTRO. Rua Simeão Camargo Varela de Sá, 03. CEP 85040-080 Guarapuava (PR), Brazil. E-mail: mmuller@unicentro.br, jkawakami@unicentro.br

(4) Researcher, Empresa Brasileira de Pesquisa Agropecuária - Embrapa Soja. Rua Carlos João Strass, Bairro Warta. CEP 86001970 Londrina (PR), Brazil. E-mail: salvador.foloni@cnpso.embrapa.br

(5) Master's Student, Graduate Studies in Agronomy, UNICENTRO. E-mail: ronaldonasc@yahoo.com.br 


\title{
RESUMO: FERTILIDADE DO SOLO, NUTRIÇÃO E PRODUTIVIDADE DE MILHO E CEVADA COM APLICAÇÃO DE GESSO AGRÍCOLA NA SUPERFÍCIE DO SOLO EM PLANTIO DIRETO
}

\begin{abstract}
A produtividade e a nutrição de culturas anuais têm apresentado respostas diferenciadas às alterações nos atributos químicos do solo promovidas pela aplicação de gesso agrícola. O objetivo deste trabalho foi avaliar o efeito de doses de gesso agrícola nos atributos químicos de um Latossolo Bruno e na nutrição e produtividade da sucessão milho-cevada sob plantio direto. O experimento foi iniciado em novembro de $2009 \mathrm{em}$ Guarapuava, PR, aplicando-se doses de 0,0; 1,5; 3,0; 4,5; e 6,0 Mg ha-1 de gesso na superfície do solo, no momento da semeadura do milho, que foi sucedido pela cevada. A aplicação do gesso reduziu os teores de $\mathrm{Al}^{3+} \mathrm{Mg}^{2+}$ na camada de 0,0-0,1 m e elevou o $\mathrm{pH}$ do solo nas camadas entre 0,2-0,6 $\mathrm{m}$ de profundidade. As doses de gesso aumentaram os teores de $\mathrm{Ca}^{2+}$ em todas as camadas até a profundidade de 0,6 m; e os de $\mathrm{S}_{-} \mathrm{SO}_{4}{ }^{2-}$, até $0,8 \mathrm{~m}$. Nas duas culturas, os teores foliares de Ca e S aumentaram e os de Mg diminuíram em razão das doses de gesso. Houve efeito das doses gesso também sobre a produtividade, com resposta quadrática do milho e aumento linear no caso da cevada, sendo os acréscimos de produtividade de até 11 e $12 \%$ superiores à testemunha, respectivamente nas doses de máxima eficiência técnica (MET) de 3,8 e 6,0 $\mathrm{Mg} \mathrm{ha}^{-1}$ de gesso. A aplicação de gesso melhorou a fertilidade do solo no perfil, sobretudo em subsuperfície, e a nutrição das plantas, elevando a produtividade do milho e da cevada.
\end{abstract}

Termos de indexação: fosfogesso, saturação de cálcio, enxofre, Zea mays, Hordeum vulgare.

\section{INTRODUCTION}

Cultivated area under no-till (NT) has significantly increased in Brazil in recent decades (Mello \& Raij, 2006), totalizing more than 32 million hectares (Febrapdp, 2011). The wide adoption of NT is due to the advantages of this conservationist management system in tropical and subtropical regions, mainly because it is less costly and less time consuming, controls hydric soil erosion, reduces production costs, and increases soil organic matter and fertility (Romeiro, 1998).

In areas with consolidated NT, due to the absence of soil tillage operations, soil acidity is corrected with surface applications of soil amendments, normally using lime rates equivalent to $50 \%$ of the lime requirement of the soil, considering the $0-20 \mathrm{~cm}$ layer. Furthermore, due to the fact that lime has lower solubility and vertical mobility in the soil profile than gypsum, especially in clayey soils (Amaral et al., 2004), subsurface layers show $\mathrm{Al}^{3+}$ toxicity and, or, $\mathrm{Ca}^{2+}$ deficiency increasingly with time, limiting root development and, therefore, decreasing water and nutrient uptake by plants, resulting in recurrent yield reduction when little or poor rainfall distribution occurs (Caires et al., 2001).

Gypsum is not a soil acidity amendment. It is a source of $\mathrm{Ca}^{2+}$ and sulfate $\left(\mathrm{SO}_{4}{ }^{2-}\right.$ ), and due to its high solubility when compared to lime, it exhibits expressive mobility in the soil profile, improving the root environment in deeper layers by the supply of $\mathrm{Ca}^{2+}$ and decrease in $\mathrm{Al}^{3+}$ activity (Ramos et al., 2006) when $\mathrm{Al}^{3+}$ associates with $\mathrm{SO}_{4}^{2-}$ (Caires et al., 2003). The enhancement of soil fertility in the subsurface layers allows greater root development, favoring the uptake and recycling of nutrients, such as $\mathrm{N}$, mainly in the nitrate $\left(\mathrm{NO}_{3}{ }^{-}\right)$form, which are carried to deeper soil layers.

Traditionally studied in regions with a dry winter in central Brazil, especially in Cerrado (Brazilian tropical savanna) soils, gypsum application has also been evaluated in NT in southern Brazil. The effects on soil chemical properties have proven to be consistent, with the intensity of variations depending on local edaphic, climatic, and management conditions. Increases in $\mathrm{Ca}^{2+}, \mathrm{SO}_{4}{ }^{2-}$, and $\mathrm{Mg}^{2+}$ levels at deeper soil layers are common results for gypsum field experiments (Caires et al., 2003; Rampim et al., 2011).

However, the effects of gypsum on crop yield have proven to be more variable. Grasses like maize (Zea mays), wheat (Triticum aestivum), and barley (Hordeum vulgare) have shown significant yield increases with gypsum application (Rashid et al., 2008; Caires et al., 2001, 2011b), while legumes like soybean (Glycine max) have shown no yield effect (Caires et al., 2011a). For plant nutrition, both grasses and legumes have shown significant responses to gypsum application, with increases in leaf levels of $\mathrm{Ca}$ and $\mathrm{S}$, and a decrease in Mg levels (Caires et al., 2003).

The aim of this study was to evaluate the effects of gypsum application rates on the chemical properties of an Oxisol and on the nutrition and yield of maize and barley under NT. The hypothesis is that gypsum application may improve plant nutrition and yield in the NT system due to its effect of decreasing aluminum levels and increasing $\mathrm{Ca}$ and $\mathrm{S}$ availability throughout the soil profile. 


\section{MATERIALS AND METHODS}

The study began in November 2009 in the Experimental Field of the Universidade Estadual do Centro-Oeste in Guarapuava, Parana, Brazil, where the climate is Humid Subtropical Mesothermal - Cfb (Wagner et al., 2009). Figure 1 shows the rainfall and temperature data throughout the period of study obtained from a meteorological station $\left(25^{\circ} 23^{\prime} \mathrm{S}\right.$, $51^{\circ} 30^{\prime} \mathrm{W}$ and $1,026 \mathrm{~m}$ asl) from the Agronomic Institute of Paraná (IAPAR), $200 \mathrm{~m}$ away from the study area, which had been managed under NT for at least 10 years. From 2005-2009, there was the following crop succession: maize for silage in summer; oat + Italian ryegrass as soil cover in winter. Soil morphological and chemical characterization plus clay content determination were carried out in October 2009 (Table 1), and the soil was classified as a Latossolo Bruno (Clayey Oxisol) (Embrapa, 2006).

A randomized complete block design was used, with four replications, and plots of $16 \times 6.4 \mathrm{~m}$. The

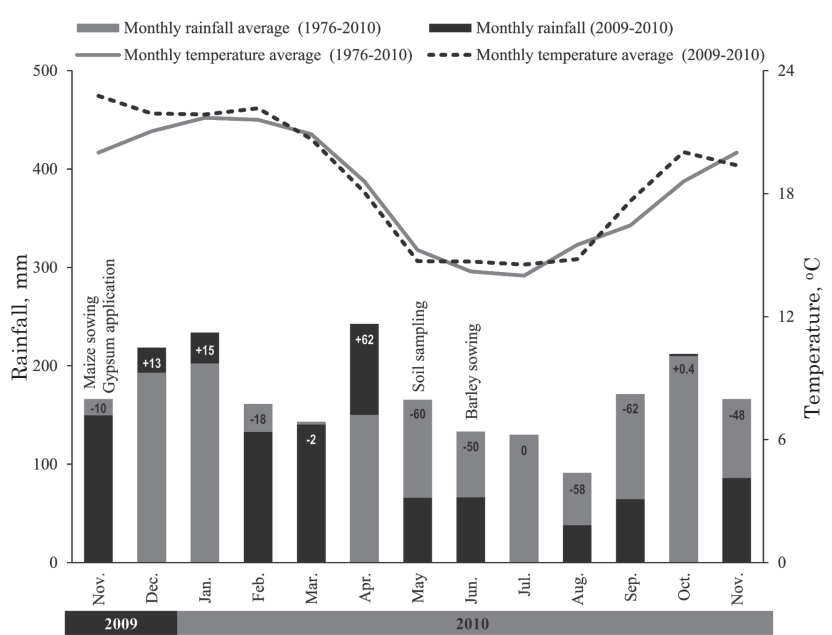

Figure 1. Historical (1976-2010) and observed (Nov/ 09 to Nov/10) averages of rainfall and temperature at Guarapuava, Parana, Brazil. Values inside the bars indicate the difference (\%) between historical and observed rainfall during the experimental period. treatments consisted of four rates of gypsum $(17 \% \mathrm{Ca}$; $14 \% \mathrm{~S} ; 0.2 \% \mathrm{P}$, and $13 \%$ moisture): $1.5,3.0,4.5$, and $6.0 \mathrm{Mg} \mathrm{ha}^{-1}$ (dry weight), plus a control treatment (without gypsum). The rates were applied on the soil surface soon after maize (Premium Flex ${ }^{\circledR}$ ) was sown on November 10, 2009, with row spacing of $0.8 \mathrm{~m}$ and an adjusted stand of 65,000 plants ha ${ }^{-1}$. Fertilization in the planting furrow was $300 \mathrm{~kg} \mathrm{ha}^{-1}$ of the 08-28-16 NPK formulation, plus side-dressing fertilizations with urea in two applications at the V4 and V6 stage (Ritchie et al., 1993), for a total of $140 \mathrm{~kg} \mathrm{ha}^{-1}$ N. Barley (BRS Cauê ${ }^{\circledR}$ ) was sown on July 6 , 2010 with row spacing of $0.17 \mathrm{~m}$ and an adjusted stand of 250 plants $\mathrm{m}^{-2}$. The fertilization on the planting furrow was $250 \mathrm{~kg} \mathrm{ha}^{-1}$ of the 08-30-20 NPK formulation, plus a side-dressing fertilization with $60 \mathrm{~kg} \mathrm{ha}^{-1} \mathrm{~N}$ at tillering.

Leaf tissue sampling was performed when $50 \%$ or more of the plants were at the $\mathrm{R} 1$ stage for maize (Ritchie et al., 1993) and 10.5 in the Feekes-Large system for barley (Large, 1954) in the central areas of each plot, sampling the ear leaf for maize (30 per plot), opposite and below the ear, and the flag leaf for barley (60 per plot). The levels of $\mathrm{P}, \mathrm{K}, \mathrm{Ca}, \mathrm{Mg}$, and $\mathrm{S}$ in the leaves were determined after nitric-perchloric digestion, and the levels of $\mathrm{N}$ after sulfuric digestion (Malavolta, 1997).

When the crops achieved physiological maturation, they were harvested manually to estimate yield, also from the central areas of the plots: $12.8 \mathrm{~m}^{2}$ per plot for maize and three sub-samples of $1.0 \mathrm{~m}^{2}$ of each per plot for barley, taking the average of the three observations as the mean of the plot. Grain weight was adjusted to the moisture of $130 \mathrm{~g} \mathrm{~kg}^{-1}$.

The soil was sampled six months after gypsum application (May 2010), between maize harvest and barley sowing, with 12 sub-samples per plot forming composite samples of each soil layer: 0.0-0.1, 0.1-0.2, 0.2-0.4, 0.4-0.6, and 0.6-0.8 $\mathrm{m}$ depth. Soil chemical analysis was carried out according to Pavan et al. (1992) to determine organic carbon (OC), $\mathrm{pH}$ in $\mathrm{CaCl}_{2}$, $\mathrm{Al}^{3+}, \mathrm{H}+\mathrm{Al}, \mathrm{Ca}^{2+}, \mathrm{Mg}^{2+}, \mathrm{K}^{+}$and $\mathrm{P}$ (Mehlich-1). For $\mathrm{S}^{-S}{ }_{4}$, the extracted was performed with $0.01 \mathrm{~mol} \mathrm{~L}^{-1}$ calcium phosphate (Cantarella \& Prochnow, 2001) and determined by the turbidimetric method (Vitti \& Suzuki, 1978).

Table 1. Morphological and chemical characterization plus clay content of the Oxisol at the experimental site before study start, in October 2009

\begin{tabular}{|c|c|c|c|c|c|c|c|c|c|c|c|c|c|c|c|c|}
\hline Hor. ${ }^{(1)}$ & Depth & $\mathrm{OC}^{(2)}$ & $\mathbf{P}^{(3)}$ & $\mathrm{S}_{-} \mathrm{SO}_{4}{ }^{2-}$ & $\mathrm{pH}\left(\mathrm{CaCl}_{2}\right)$ & Al & $\mathbf{H}+\mathrm{Al}$ & $\mathbf{C a}$ & Mg & $\mathbf{K}$ & $\mathrm{V}^{(4)}$ & $\mathrm{Fe}$ & $\mathrm{Cu}$ & $\mathrm{Zn}$ & $M n$ & Clay $^{(5)}$ \\
\hline & $\mathrm{m}$ & $\mathrm{g} \mathrm{dm}^{-3}$ & \multicolumn{2}{|c|}{$-\mathrm{mgdm} \mathrm{m}^{-3}-$} & & \multicolumn{5}{|c|}{$\mathrm{cmol}_{\mathrm{c}} \mathrm{dm}^{-3}$} & $\%$ & \multicolumn{4}{|c|}{$-\mathrm{mgdm} \mathrm{m}^{-3}$} & $\%$ \\
\hline $\mathrm{A} 1$ & $0.0-0.3$ & 21 & 1.1 & 4.7 & 5.4 & 0.20 & 4.96 & 5.01 & 2.66 & 0.26 & 61 & 52.4 & 2.33 & 3.15 & 54.3 & 72 \\
\hline $\mathrm{AB} 1$ & $0.3-0.5$ & 21 & 0.3 & 10.5 & 4.5 & 0.40 & 7.66 & 1.10 & 1.07 & 0.08 & 22 & 40.9 & 0.39 & 2.38 & 16.3 & 79 \\
\hline $\mathrm{AB} 2$ & $0.5-0.8$ & 11 & 0.5 & 13.3 & 4.7 & 0.40 & 6.18 & 0.85 & 1.14 & 0.04 & 25 & 32.3 & 0.29 & 1.93 & 18.9 & 81 \\
\hline $\mathrm{BA}$ & $0.8-1.1$ & 10 & 0.3 & 4.4 & 4.7 & 0.00 & 5.74 & 0.65 & 0.76 & 0.04 & 20 & 30.8 & 0.32 & 1.66 & 12.6 & 83 \\
\hline B & $1.1-1.4+$ & 06 & 0.2 & 3.8 & 5.3 & 0.00 & 3.68 & 0.29 & 0.22 & 0.04 & 13 & 41.3 & 0.36 & 1.10 & 8.21 & 82 \\
\hline
\end{tabular}

(1) Pedological horizon; (2) OC: Organic carbon; ${ }^{(3)} \mathrm{P}$ extracted by Mehlich-1 (Pavan et al., 1992); (4) V: base saturation; ${ }^{(5)}$ Clay content (Embrapa, 1997). 
The results were subjected to analysis of variance and, in the case of significance $(\mathrm{p}<0.05)$, regression analysis was also performed, fitting models as a function of gypsum rates and adopting the model with the highest level of significance. Correlation analysis was also performed for some data in order to complement the results discussion.

\section{RESULTS AND DISCUSSION}

The gypsum application rates had no significant effect on soil $\mathrm{pH}$ at depths of $0.0-0.1,0.1-0.2$, and 0.6-0.8 $\mathrm{m}$ (Figure 2a), with the same happening for $\mathrm{H}+\mathrm{Al}$ in all the soil layers studied (Figure 2b). As gypsum is a neutral salt and has no corrective properties on soil acidity, changes in soil $\mathrm{pH}$ and $\mathrm{H}+\mathrm{Al}$ are not expected due to its application (Raij, 2008). These results are in agreement with those from Caires et al. (2002; 2004), who observed no effect of gypsum on soil $\mathrm{pH}$ up to a depth of $0.4 \mathrm{~m}$ and on $\mathrm{H}+\mathrm{Al}$ up to a depth of $0.8 \mathrm{~m}$ in a medium-textured Latossolo Vermelho (Oxisol) of Ponta Grossa, PR.

However, soil pH was increased by gypsum application in layers from 0.2-0.6 m (Figure 2a). The $\mathrm{S}-\mathrm{SO}_{4}{ }^{2-}$ added by gypsum is strongly repelled from near surface layers in soils that are relatively high in organic matter $(\mathrm{OM})$ due to predominant negative charges and displacement from positive charges by phosphate. In subsurface layers and in high concentrations, $\mathrm{S}_{-} \mathrm{SO}_{4}{ }^{2-}$ reacts with $\mathrm{Fe}$ and $\mathrm{Al}$ oxides (hydroxides), releasing $\mathrm{OH}^{-}$ions in the soil solution and leading to a small increase on $\mathrm{pH}$ (Raij, 2008). These results are corroborated by Caires et al. (1999), who also reported an increase on soil $\mathrm{pH}$ at 18 and 40 months after gypsum application in layers from 0.2-0.8 $\mathrm{m}$ in an Oxisol. Despite the statistical significance of this effect and the possible improvement in root environment caused by gypsum, the $\mathrm{pH}$ changes recorded are not sufficient to lead to substantial modifications in soil chemical reaction to the point of considering it a neutralization reaction, as caused by lime application (Raij, 2008).

Levels of $\mathrm{Al}^{3+}$ showed a linear decrease in the 0.0-0.1 m layer as a function of gypsum rates (Figure $2 c$ ). The observation of negative correlation between

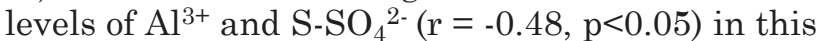
layer provided evidence that the $\mathrm{S}_{-} \mathrm{SO}_{4}{ }^{2-}$ increases led to the formation of ionic pairs between $\mathrm{Al}^{3+}$ and $\mathrm{S}-\mathrm{SO}_{4}{ }^{2-}$, such as $\mathrm{AlSO}_{4}{ }^{+}$, which decreases the activity of $\mathrm{Al}^{3+}$ in the soil solution and is more readily leached from surface layers due to lower valence in comparison to $\mathrm{Al}^{3+}$ (Zambrosi et al., 2007). The $\mathrm{Al}^{3+}$ levels in the 0.0-0.1 m layer (Figure 2c) were also negatively correlated with maize yield $(\mathrm{r}=-0.50, \mathrm{p}<0.05)$ and barley yield $(r=-0.46, p<0.05)$, indicating that the decrease in the $\mathrm{Al}^{3+}$ level caused by gypsum application was beneficial to the yield of both crops.
Gypsum application rates brought about linear increases in $\mathrm{S}_{-} \mathrm{SO}_{4}{ }^{2-}$ levels in all the soil layers evaluated, which was due to the gypsum composition, with $14 \%$ (mass) of $\mathrm{S}$. In addition, the relatively low retention and high leaching of $\mathrm{S}_{-} \mathrm{SO}_{4}{ }^{2-}$ from near surface layers was evidenced by the higher levels of $\mathrm{S}_{-} \mathrm{SO}_{4}{ }^{2-}$ in deeper layers, mainly at higher gypsum rates (Figure 2d). Accumulated rainfall in the first six months after gypsum application, i.e., up to soil sampling, was $1,180 \mathrm{~mm}$ and proved to be enough to bring about significant movement of $\mathrm{S}_{-} \mathrm{SO}_{4}{ }^{2-}$ to the deepest layer evaluated. Various authors have already reported that vertical movement of $\mathrm{S}_{-} \mathrm{SO}_{4}{ }^{2-}$ depends on the soil texture and hydrological regime, being slower in clayey soils and/or drier regions (Caires et al., 2004; Raij, 2008).

There was no effect of gypsum on $\mathrm{P}$ levels (Figure 2e), countering the results of Caires et al. (2011b), which showed a linear increase in $\mathrm{P}$ in the 0.00-0.05 and 0.05-0.10 $\mathrm{m}$ layers due to gypsum application in another Oxisol from Guarapuava. This divergence might be due to differences in soil sampling, depending on the proportion of sub-samples between rows and in rows since soil sampling in the row has a strong effect on $\mathrm{P}$ fertilization in the furrow during sowing. Another possibility is a difference in the residual levels of $\mathrm{P}$ in the gypsum, which are variable according to the isomorphic substitutions in the phosphatic rock used to produce the phosphoric acid (Raij, 2008), because gypsum is a byproduct of this reaction.

The $\mathrm{Ca}^{2+}$ levels exhibited a linear increase in layers between 0.0-0.6 $\mathrm{m}$ after gypsum application (Figure $3 \mathrm{a}$ ), which is explained by the presence of $17 \%$ of $\mathrm{Ca}^{2+}$ in the gypsum composition. Increases in the $\mathrm{Ca}^{2+}$ level through the soil profile is considered a differential and positive effect of gypsum in comparison to lime, improving subsurface soil fertility regardless of tillage. Ernani et al. (2001) reported greater and faster vertical movement of $\mathrm{Ca}^{2+}$ in the soil profile by gypsum application in comparison to calcitic lime application. According to Caires et al. (2011b), the movement of $\mathrm{Ca}^{2+}$ in the soil profile depends on the gypsum rates applied, soil texture, and volume of accumulated rainfall. In the present study, the relatively fast vertical movement of $\mathrm{Ca}^{2+}$, considering the clayey texture, can be attributed to the rainfall $(1,180 \mathrm{~mm})$ and the fact that 20-30\% of the applied gypsum may have remainded in the form of $\mathrm{CaSO}_{4}{ }^{0}$ (Pavan et al., 1984), which due to zero valence has greater vertical mobility. Rampim et al. (2011) verified expressive increases in $\mathrm{Ca}^{2+}$ levels in the 0.0-0.4 m layer nine months after gypsum application in a clayey Oxisol from Guaira, PR.

The levels of $\mathrm{Mg}^{2+}$ decreased in the 0.0-0.1 m layer due to gypsum application (Figure 3b). Adding increasing amounts of $\mathrm{Ca}^{2+}$ to the soil by gypsum may release part of the $\mathrm{Mg}^{2+}$ that was adsorbed on soil colloids, displacing them to the soil solution to be taken 
up by plants and, or, react with $\mathrm{SO}_{4}{ }^{2-}$. If the ionic pair $\mathrm{MgSO}_{4}{ }^{0}$ is formed, it may easily be moved to deeper soil layers due to its valence. Studying ionic speciation in a dystrophic Oxisol after gypsum application, Zambrosi et al. (2007) observed that $\mathrm{SO}_{4}{ }^{2-}$ was the inorganic anion that most interacted with $\mathrm{Mg}^{2+}$, supporting the inferences of vertical movement of both ions through the soil profile.
In the layers from 0.1-0.4 $\mathrm{m}$, there was a linear increase in $\mathrm{Mg}^{2+}$ levels (Figure $3 \mathrm{~b}$ ), confirming that the addition of gypsum can lead to the redistribution of this nutrient in the soil profile. The increases in subsurface layers occur by dissociation of $\mathrm{MgSO}_{4}{ }^{0}$ since the anion $\mathrm{SO}_{4}{ }^{2-}$ is more strongly adsorbed in more acidic and less electronegative soil, typical characteristics of subsurface layers (Raij, 2008). The improvement in soil fertility at deeper layers brought
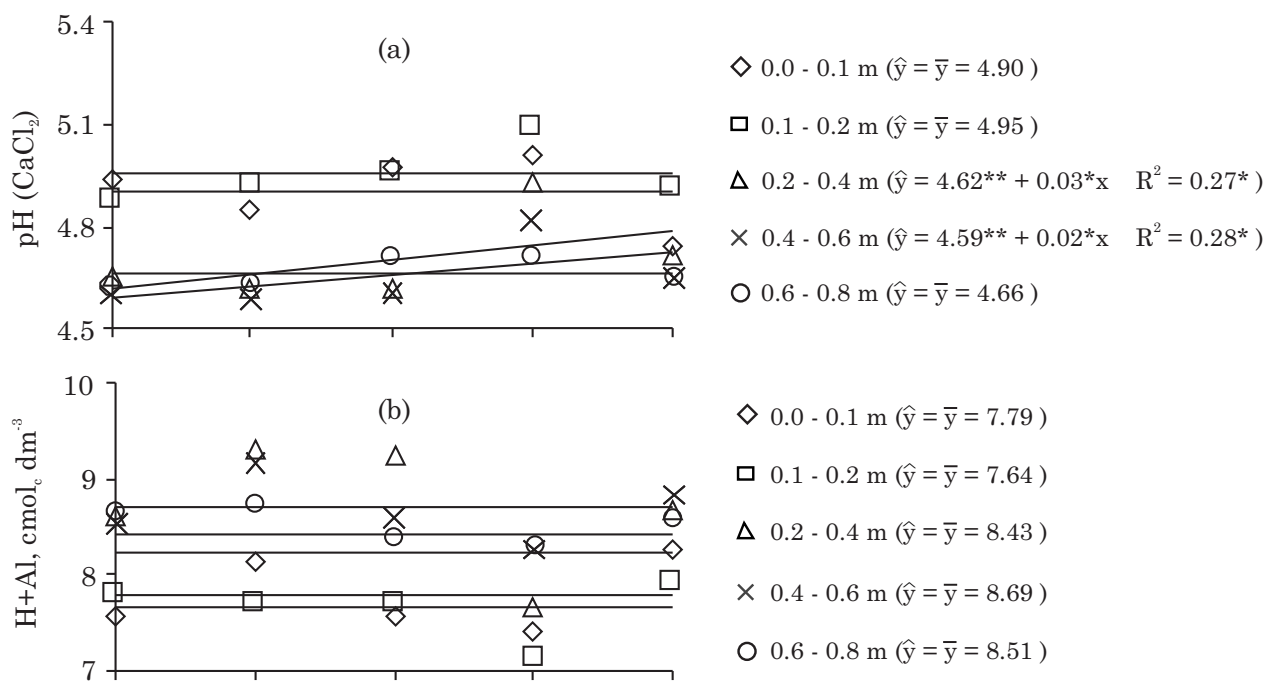

$\diamond 0.0-0.1 \mathrm{~m}(\hat{\mathrm{y}}=\overline{\mathrm{y}}=7.79)$

ㅁ $0.1-0.2 \mathrm{~m}(\hat{\mathrm{y}}=\overline{\mathrm{y}}=7.64)$

$\Delta 0.2-0.4 \mathrm{~m}(\hat{\mathrm{y}}=\overline{\mathrm{y}}=8.43)$

$\times 0.4-0.6 \mathrm{~m}(\hat{\mathrm{y}}=\overline{\mathrm{y}}=8.69)$

$0.6-0.8 \mathrm{~m}(\hat{\mathrm{y}}=\overline{\mathrm{y}}=8.51)$

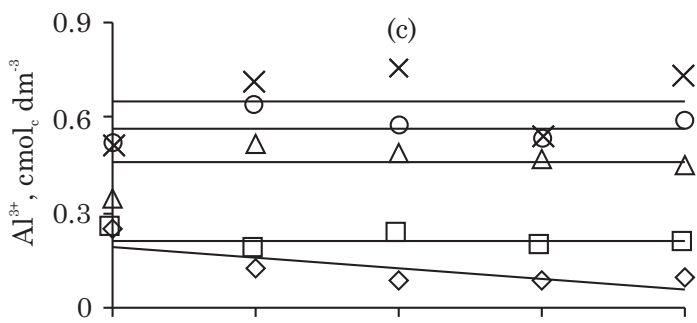

$\diamond 0.0-0.1 \mathrm{~m}\left(\hat{\mathrm{y}}=0.19^{* *}-0.02^{* *} \mathrm{x} \quad \mathrm{R}^{2}=0.59^{* *}\right)$

무 $0.1-0.2 \mathrm{~m}(\hat{\mathrm{y}}=\overline{\mathrm{y}}=0.22)$

$\Delta 0.2-0.4 \mathrm{~m}(\hat{\mathrm{y}}=\overline{\mathrm{y}}=0.45)$

$\times 0.4-0.6 \mathrm{~m}(\hat{\mathrm{y}}=\overline{\mathrm{y}}=0.65)$

$0.6-0.8 \mathrm{~m}(\hat{\mathrm{y}}=\overline{\mathrm{y}}=0.57)$

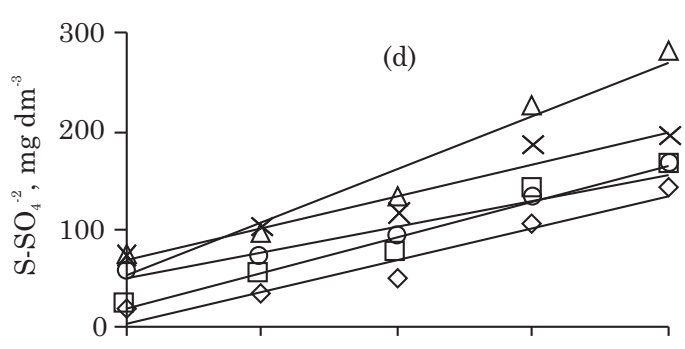

$\diamond 0.0-0.1 \mathrm{~m}\left(\hat{\mathrm{y}}=5.57+21.39^{* *} \mathrm{x} \quad \mathrm{R}^{2}=0.94^{* *}\right)$

ㅁ $0.1-0.2 \mathrm{~m}\left(\hat{\mathrm{y}}=17.84^{*}+24.58^{* *} \mathrm{x} \quad \mathrm{R}^{2}=0.97 * *\right)$

$\Delta 0.2-0.4 \mathrm{~m}\left(\hat{\mathrm{y}}=53.65^{* *}+35.82^{* *} \mathrm{x} \quad \mathrm{R}^{2}=0.95^{* *}\right)$

$\times 0.4-0.6 \mathrm{~m}\left(\hat{\mathrm{y}}=68.65^{* *}+21.74^{* *} \mathrm{x} \quad \mathrm{R}^{2}=0.93^{* *}\right)$

$0.6-0.8 \mathrm{~m}\left(\hat{\mathrm{y}}=47.59^{* *}+17.81^{* *} \mathrm{x} \quad \mathrm{R}^{2}=0.97 * *\right)$

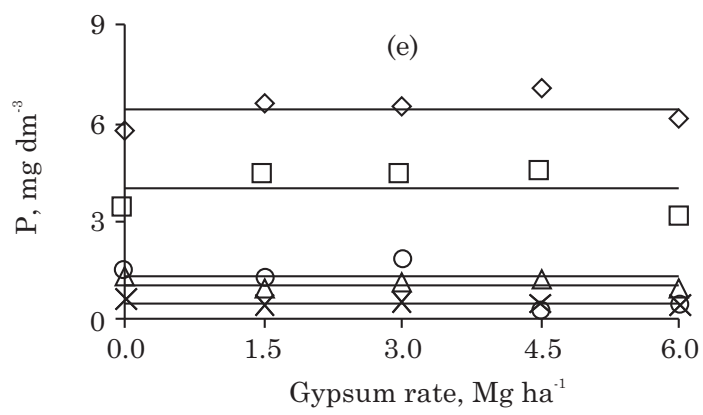

$\diamond 0.0-0.1 \mathrm{~m}(\hat{\mathrm{y}}=\overline{\mathrm{y}}=6.41)$

ㅁ $0.1-0.2 \mathrm{~m}(\hat{\mathrm{y}}=\overline{\mathrm{y}}=3.93)$

$\Delta 0.2-0.4 \mathrm{~m}(\hat{\mathrm{y}}=\overline{\mathrm{y}}=1.13)$

$\times 0.4-0.6 \mathrm{~m}(\hat{\mathrm{y}}=\overline{\mathrm{y}}=0.50)$

$0.6-0.8 \mathrm{~m}(\hat{\mathrm{y}}=\overline{\mathrm{y}}=1.04)$

Figure 2. Active $(\mathrm{pH})$ and potential $(\mathrm{H}+\mathrm{Al})$ soil acidity, exchangeable aluminum $\left(\mathrm{Al}^{3+}\right)$, sulfur $(\mathrm{S})$, and phosphorus $(\mathrm{P})$ levels in soil layers, six months after surface application of gypsum under a no-till system. $* \mathrm{p}<0.05$ and $* * \mathrm{p}<0.01$. 
about by movement of basic cations, in this case $\mathrm{Mg}^{2+}$, in the soil profile is a positive effect of gypsum since any decline in this nutrient levels at surface layers, were enough to achieve the point to cause $\mathrm{Mg}$ deficiency on crops.

There was no effect of gypsum on soil $\mathrm{K}^{+}$levels (Figure 3c), indicating that the rates applied did not lead to leaching of this cation. In contrast with $\mathrm{Mg}^{2+}$, vertical movement of $\mathrm{K}^{+}$in the profile through gypsum applications have been smaller (Caires et al., 2002) and more common when the soil $\mathrm{K}^{+}$levels are considered high. This result agrees with results from Caires et al. (2004), who observed no effect of gypsum rates on soil $\mathrm{K}^{+}$levels.
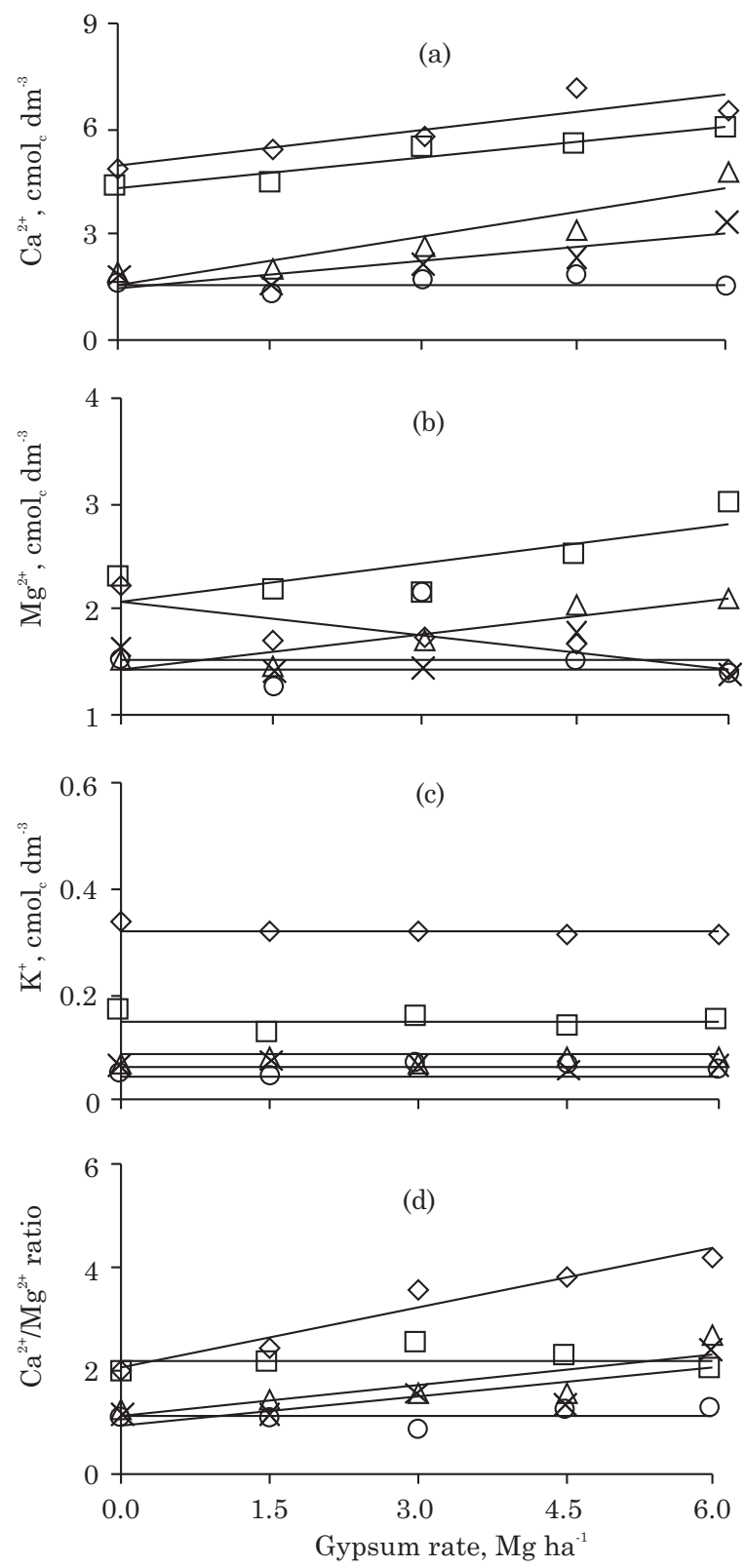

The soil $\mathrm{Ca}^{2+} / \mathrm{Mg}^{2+}$ ratio increased in a linear manner in the soil, except for the 0.1-0.2 and 0.6-0.8 m layers (Figure 3d). This is explained by the competition between these cations for adsorption sites (Foloni et al., 2008) and reflect their isolated behavior, which showed an increase in $\mathrm{Ca}^{2+}$ levels along the soil profile, except for the 0.6-0.8 m layer, and movement of $\mathrm{Mg}^{2+}$ from the 0.0-0.1 to 0.1-0.2 and 0.2-0.4 m layer, enough to counter the $\mathrm{Ca}^{2+}$ increase in the 0.1-0.2 m layer.

Ribas (2010) evaluated 1,217 soil chemical analyses in the same municipality as this study and reported that $48.7 \%$ of the samples had intermediate $\mathrm{Ca}^{2+} / \mathrm{Mg}^{2+}$ values $\left(1.5<\mathrm{Ca}^{2+} / \mathrm{Mg}^{2+}<3.5\right)$, and another $48.8 \%$ had low values $\left(\mathrm{Ca}^{2+} / \mathrm{Mg}^{2+} \leq 1.5\right)$ according to Kelling \& Peters (2004). These results

$$
\begin{array}{ll}
\diamond 0.0-0.1 \mathrm{~m}\left(\hat{\mathrm{y}}=2.05^{* *}-0.10^{*} \mathrm{x}\right. & \left.\mathrm{R}^{2}=0.77^{*}\right) \\
\text { 0.1-0.2 m ( } \mathrm{y}=2.06^{* *}+0.11^{*} \mathrm{x} & \left.\mathrm{R}^{2}=0.62^{*}\right) \\
\Delta \text { 0.2-0.4 m }\left(\hat{\mathrm{y}}=1.42^{* *}+0.11^{*} \mathrm{x}\right. & \left.\mathrm{R}^{2}=0.89^{*}\right) \\
\times 0.4-0.6 \mathrm{~m}(\hat{\mathrm{y}}=\overline{\mathrm{y}}=1.54) & \\
\text { O 0.6-0.8 m }(\hat{\mathrm{y}}=\overline{\mathrm{y}}=1.51) &
\end{array}
$$

$\diamond 0.0-0.1 \mathrm{~m}(\hat{\mathrm{y}}=\overline{\mathrm{y}}=0.32)$

ㅁ $0.1-0.2 \mathrm{~m}(\hat{\mathrm{y}}=\overline{\mathrm{y}}=0.15)$

$\Delta$ 0.2-0.4 m $(\hat{\mathrm{y}}=\overline{\mathrm{y}}=0.08)$

$\times 0.4-0.6 \mathrm{~m}(\hat{\mathrm{y}}=\overline{\mathrm{y}}=0.06)$

O $0.6-0.8 \mathrm{~m}(\hat{\mathrm{y}}=\overline{\mathrm{y}}=0.05)$

$$
\begin{array}{ll}
\diamond 0.0-0.1 \mathrm{~m}\left(\hat{\mathrm{y}}=2.04^{* *}+0.39^{*} \mathrm{x}\right. & \left.\mathrm{R}^{2}=0.94^{* *}\right) \\
\square \text { 0.1-0.2 m }(\hat{\mathrm{y}}=\overline{\mathrm{y}}=2.19) & \\
\Delta \text { 0.2-0.4 m }\left(\hat{\mathrm{y}}=1.09^{* *}+0.20^{* *} \mathrm{x}\right. & \left.\mathrm{R}^{2}=0.70^{* *}\right) \\
\times 0.4-0.6 \mathrm{~m}\left(\hat{\mathrm{y}}=0.93^{* *}+0.19^{* *} \mathrm{x}\right. & \left.\mathrm{R}^{2}=0.68^{* *}\right) \\
\text { O 0.6-0.8 m }(\hat{\mathrm{y}}=\overline{\mathrm{y}}=1.07) &
\end{array}
$$

Figure 3. Contents of calcium $\left(\mathrm{Ca}^{2+}\right)$, magnesium $\left(\mathrm{Mg}^{2+}\right)$, potassium $\left(\mathrm{K}^{+}\right)$, and $\mathrm{Ca}^{2+} / \mathrm{Mg}^{2+}$ ratio in soil layers, six months after surface application of gypsum under a no-till system. $*$ p $<0.05$ and $* *$ p $<0.01$. 
were attributed to the widespread and long-term use of dolomitic lime in the region. For that reason, the increase in the $\mathrm{Ca}^{2+} / \mathrm{Mg}^{2+}$ ratio brought about by gypsum can be beneficial to crops, as reported by Caires et al. (2011b), who evaluated gypsum rates in Guarapuava, PR, verifying that maize yield was positively correlated with the soil $\mathrm{Ca}^{2+} / \mathrm{Mg}^{2+}$ ratio.

As for the nutritional status of the crops, gypsum application led to a linear increase in leaf content of $\mathrm{N}$ in maize; however, there was no effect in barley (Figure 4a). The higher fertility in deeper soil layers with gypsum, through the increase on $\mathrm{pH}$ values and levels of $\mathrm{Ca}^{2+}$ and $\mathrm{Mg}^{2+}$, would permit greater distribution of roots in deeper layers, giving opportunity to the crops to recover greater amounts of water and nutrients, especially those species with deeper root systems and those nutrients that might easily be leached, like $\mathrm{N}$ in the nitrate $\left(\mathrm{NO}_{3}{ }^{-}\right)$form. Caires et al. (2004) and Matula \& Pechová (2007) reported enhancements in $\mathrm{N}$ leaf content in maize and barley, respectively, by gypsum application, with the effects being attributed to improvement in subsoil fertility and better relative distribution of the root system at greater depth.

The leaf contents of $\mathrm{P}$ (Figure 4b) and K (Figure 4c) were not affected by gypsum in either crop, corroborating Raij et al. (1998) for maize, and Caires et al. (2001) for barley. The lack of effect of gypsum on the leaf content of these nutrients reflected their behavior in the soil since they were not affected by gypsum application rates in any of the soil layers evaluated (Figures $2 \mathrm{e}$ and $3 \mathrm{c}$ ).

In contrast, leaf contents of $\mathrm{Ca}$ (Figure $4 \mathrm{~d}$ ) and $\mathrm{S}$ (Figure 4f) were both enhanced in maize and barley through gypsum application. The increase in the leaf content of these nutrients agree with their increased levels in the soil profile due to gypsum, since gypsum is a source of these nutrients. In this study, both maize and barley yields were positively correlated $(p<0.01)$ with the leaf contents of $\mathrm{Ca}(\mathrm{r}=0.69$ and 0.52$)$ and $\mathrm{S}$
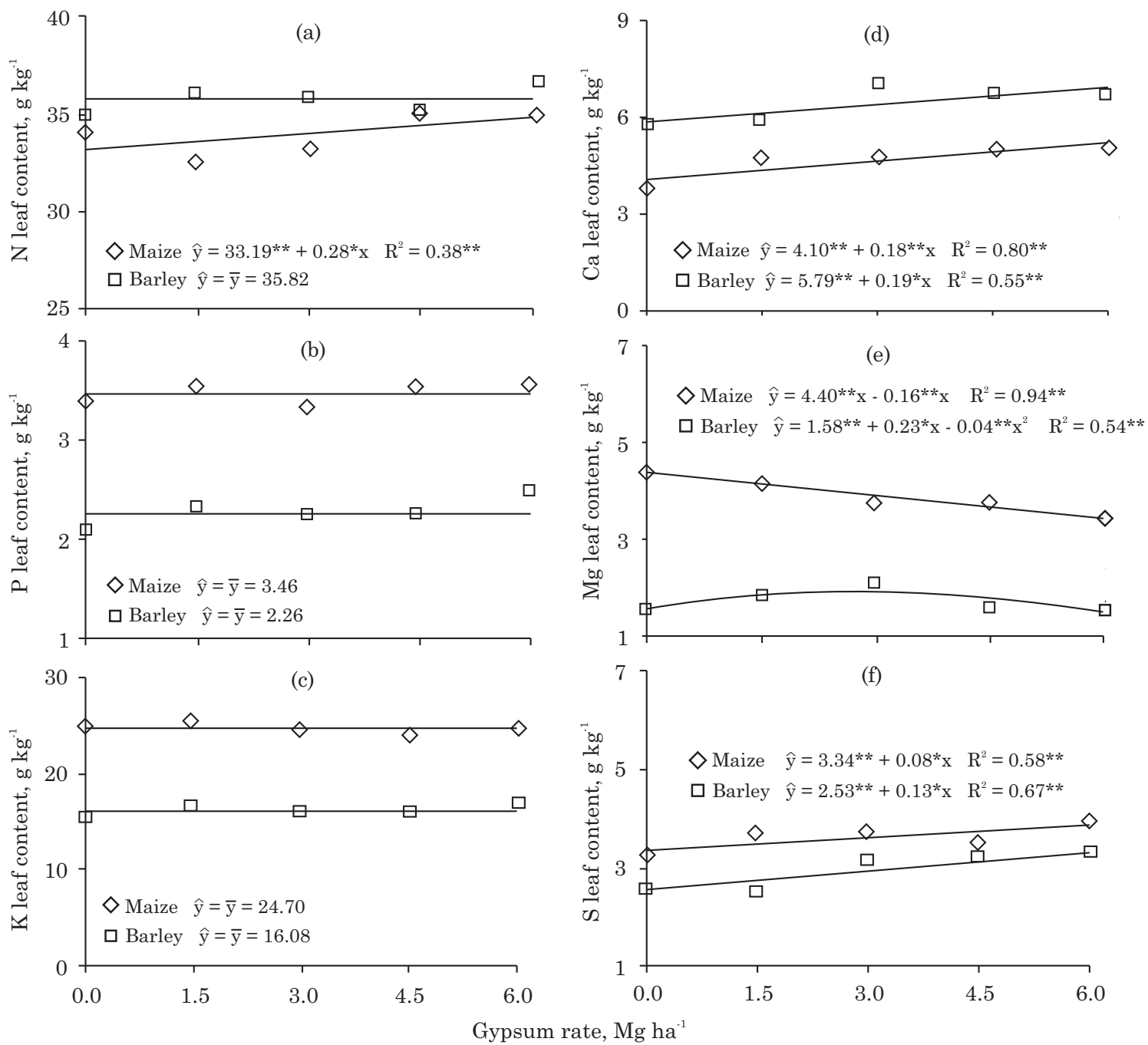

Figure 4. Leaf tissue content of nitrogen $(\mathrm{N})$, phosphorus $(\mathrm{P})$, potassium (K), calcium (Ca), magnesium (Mg), and sulfur (S) in maize and barley crops as a function of gypsum rates applied on the soil surface under a no-till system. $* p<0.05$ and $* * p<0.01$. 
$(\mathrm{r}=0.64$ and 0.57$)$, showing that the supply of these nutrients by gypsum was relevant to increasing yields. The level of $\mathrm{S}_{-} \mathrm{SO}_{4}{ }^{2-}$ in the $0.0-0.1 \mathrm{~m}$ layer of the soil under study (Table 1) is considered low according to the literature (CQFSRS/SC, 2004), and the response of crop yield to the supply of this nutrient through gypsum is an important fact in the present and for the future, considering the growing use of more concentrated NPK fertilizers over the past decades, which have a lower percentage of single superphosphate in their composition and, consequently, less gypsum, leading to minor additions of $\mathrm{S}$ to the soils and less availability of $\mathrm{S}$ to the plants.

Leaf content of $\mathrm{Mg}$ decreased in a linear manner in maize through gypsum application (Figure 4e). The $\mathrm{Mg}$ reduction concomitant with the Ca increase in the $0.0-0.1 \mathrm{~m}$ soil layer due to gypsum (Figure $3 \mathrm{~b}$ ) may have limited $\mathrm{Mg}$ availability to the crop, at least in early stages, with a negative impact on uptake (Figure 4e), due to competitive uptake between nutrients (Medeiros et al., 2008). An overall positive correlation $(\mathrm{r}=0.52, \mathrm{p}<0.05)$ of $\mathrm{Mg}$ leaf content with maize yield was recorded, but the yield response to gypsum was quadratic (Figure 5), so the first decreases in $\mathrm{Mg}$ content may not have been detrimental to yield, but beneficial. Support for this is in the sufficiency range of 2.5-4.0 $\mathrm{g} \mathrm{kg}^{-1}$ of $\mathrm{Mg}$ in maize (Martinez et al., 1999), and with 0 and $1.5 \mathrm{Mg} \mathrm{ha}^{-1}$ of gypsum, the leaf content of $\mathrm{Mg}$ remained above the sufficiency limit.

For barley, the response of $\mathrm{Mg}$ leaf content was quadratic (Figure 4e), with increases in $\mathrm{Mg}$ up to $2.9 \mathrm{Mg} \mathrm{ha}^{-1}$ of gypsum. Matula \& Pechová (2007) also observed higher $\mathrm{Mg}$ in barley after application of $3.5 \mathrm{Mg} \mathrm{ha}^{-1}$ of gypsum. The yield of barley, however, increased linearly with gypsum application (Figure 5), indicating no problem with $\mathrm{Mg}$ status in the leaves.

The quadratic response of maize yield to gypsum application rates (Figure 5) made it possible to establish maximum technical efficiency (MTE) at $3.8 \mathrm{Mg} \mathrm{ha}^{-1}$ of gypsum, with an estimated yield of $10.9 \mathrm{Mg} \mathrm{ha}^{-1}$. $11 \%$ greater than the control treatment. This result is according to Caires et al. (2011b), who evaluated

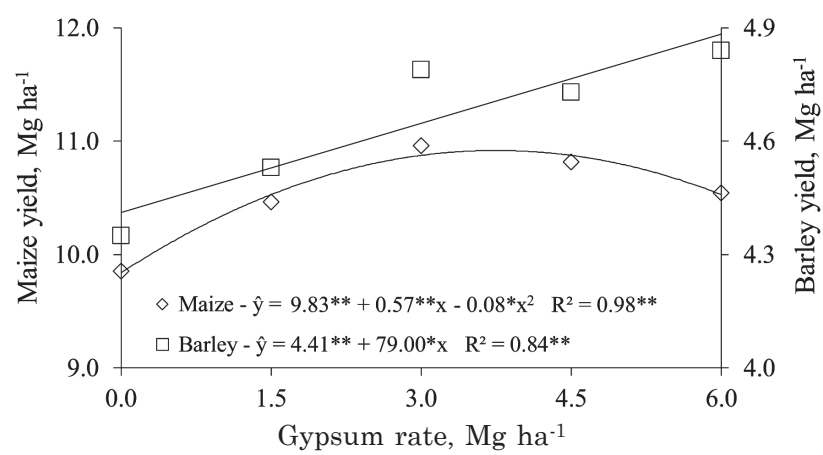

Figure 5. Yield of maize and barley at 2009-2010 and 2010 harvests as a function of gypsum rates applied on the soil surface under a no-till system. $* \mathrm{p}<0.05$ and $* * \mathrm{p}<0.01$. gypsum application in a high fertility Oxisol, also in Guarapuava, PR, reporting an increase of $11 \%$ in maize yield with an MTE of $7.8 \mathrm{Mg} \mathrm{ha}^{-1}$ of gypsum. The difference among MTEs in the same crop in two studies made in the same region shows the relevance of determining additional parameters for recommending the use of gypsum, and it is fundamental to establish the effects of this product in different initial conditions of soil fertility, mainly in relation to the levels of nutrients that can be mobilized in the soil profile.

There was a linear increase in barley yield through gypsum application (Figure 5). According to the fitted equation, the gypsum rate of $6 \mathrm{Mg} \mathrm{ha}^{-1}$ corresponded to an estimated grain yield of $4.9 \mathrm{Mg} \mathrm{ha}^{-1}, 12 \%$ greater than the control treatment. During the crop cycle (July to November 2010), rainfall was $33.5 \%$ lower than the historical mean of the period (Figure 1), and in this scenario gypsum might have contributed to an MTE with a higher gypsum rate in barley than in maize. The improvement in soil fertility and the root environment in the subsurface brought about by gypsum results in better root growth in deeper soil layers, favoring water and nutrient uptake by crops. These results are corroborated by Caires et al. (2001), who observed better relative distribution of the root system in deeper soil and an increase of $23 \%$ in barley yield with the application of $9 \mathrm{Mg} \mathrm{ha}^{-1}$ of gypsum in relation to the control, under severe water stress.

The results obtained in this work, as in another studies (Caires et al., 2011a,b; Rampim et al., 2011), showed the positive response of some crops to gypsum application, even with gypsum rates greater than the rates recommended based on clay percentage of the soil, e.g., clay $\% \times 50$ (Sousa et al., 2005) or $\times 60$ (Raij et al., 1996). Therefore, it is essential to determine parameters in addition to clay percentage for estimating the gypsum rates to be applied. It is necessary to intensify and regionalize these studies, which should last long enough to observe results for crop rotation.

\section{CONCLUSIONS}

1. Gypsum improved soil fertility in the profile, increasing levels of $\mathrm{Ca}^{2+}$ and $\mathrm{S}_{-} \mathrm{SO}_{4}{ }^{2-}$, distributing $\mathrm{Mg}^{2+}$ from surface to subsurface layers, decreasing $\mathrm{Al}^{3+}$ on the surface and slightly increasing soil $\mathrm{pH}$ in the subsurface layers.

2. Increased $\mathrm{Ca}$ and $\mathrm{S}$ in maize and barley leaves as a function of gypsum were positively correlated with grain yield, and $\mathrm{Mg}$ leaf content was positively correlated with maize yield.

3. Maize and barley responded to gypsum application, with yield increases at higher gypsum rates than the ones determined by methods traditionally based on clay content. 


\section{LITERATURE CITED}

AMARAL, A.S.; ANGHINONI, I. \& DESCHAMPS, F.C. Resíduos de plantas de cobertura e mobilidade dos produtos da dissolução do calcário aplicado na superfície do solo. R. Bras. Ci. Solo, 28:115-123, 2004.

CAIRES, E.F.; FONSECA, A.F.; MENDES, J.; CHUEIRI, W.A. \& MADRUGA, E.F. Produção de milho, trigo e soja em função das alterações das características químicas do solo pela aplicação de calcário e gesso na superfície, em sistema de plantio direto. R. Bras. Ci. Solo, 23:315-327, 1999.

CAIRES, E.F.; FELDHAUS, I.C. \& BLUM, J. Crescimento radicular e nutrição da cevada em função da calagem e aplicação de gesso. Bragantia, 60:213-223, 2001.

CAIRES, E.F.; FELDHAUS, I.C.; BARTH, G. \& GARBUIO, F.J. Lime and gypsum application on the wheat crop. Sci. Agric., 59:357-364, 2002.

CAIRES, E.F.; BLUM, J.; BARTH, G.; GARBUIO, F.J. \& KUSMAN, M.T. Alterações químicas no solo e resposta da soja ao calcário e gesso aplicados na implantação do sistema plantio direto. R. Bras. Ci. Solo, 27:275-286, 2003.

CAIRES, E.F.; KUSMAN, M.T.; BARTH, G.; GARBUIO, F.J. \& PADILHA, J.M. Alterações químicas do solo e resposta do milho à calagem e aplicação de gesso. R. Bras. Ci. Solo, 28:125-136, 2004.

CAIRES, E.F.; JORIS, H.A.W. \& CHURKA, S. Long-term effects of lime and gypsum additions on no-till corn and soybean yield and soil chemical properties in southern Brazil. Soil Use Manage., 27:45-53, 2011a.

CAIRES, E.F.; MASCHIETTO, E.H.G.; GARBUIO, F.J.; CHURKA, S. \& JORIS, H.A.W. Surface application of gypsum in low acidic Oxisol under no-till cropping system. Sci. Agric., 68:45-53, 2011b.

CANTARELLA, H. \& PROCHNOW, L.I. Determination of sulfate in soils. In: RAIJ, B.van; ANDRADE, E.; CANTARELLA, H. \& QUAGGIO, J.A., eds. Chemical analysis for evaluation on the fertility of tropical soils. Campinas, Instituto Agronômico, 2001. p.225-230.

COMISSÃO DE QUÍMICA E FERTILIDADE DO SOLO CQFSRS/SC. Manual de adubação e de calagem para os estados do Rio Grande do Sul e de Santa Catarina. 10.ed. Porto Alegre, 2004.

EMPRESA BRASILEIRA DE PESQUISA AGROPECUÁRIA EMBRAPA. Sistema brasileiro de classificação de solos. 2.ed. Rio de Janeiro, Embrapa Solos, 2006. 306p.

EMPRESA BRASILEIRA DE PESQUISA AGROPECUÁRIA EMBRAPA. Centro Nacional de Pesquisa de Solos. Manual de métodos de análise de solo. 2.ed. Rio de Janeiro, Embrapa Solos, 1997. 212p.

ERNANI, P.R.; RIBEIRO, M.S. \& BAYER, C. Modificações químicas em solos ácidos ocasionadas pelo método de aplicação de corretivos da acidez e de gesso agrícola. Sci. Agric., 58:825-831, 2001.

FEDERAÇÃO BRASILEIRA DE PLANTIO DIRETO NA PALHA - FEBRAPDP. Plantio direto em números. Available at: <http://www.febrapdp.org.br/download/ BREvolucaoPD 2008a2010.pdf>. Accessed: Jun. 10, 2013.
FOLONI, J.S.S.; SANTOS, D.H.; CRESTE, J.E. \& SALVADOR, J.P. Resposta do feijoeiro e fertilidade do solo em função de altas doses de calcário em interação com a gessagem. Colloq. Agrar., 4:27-35, 2008.

KELLING, K.A. \& PETERS, J.B. The advisability of using cation balance as a basis for fertilizer recommendations. 2004. WISCONSIN FERTLIZER, AGLIME, \& PEST MANAGEMENT CONFERENCE PROCEEDINGS. Available at: <http://www.soils.wisc.edu/extension/ wcmc/2004proceedings/Kelling1.pdf $>$. Accessed on: July $12,2013$.

LARGE, E.C. Growth stages in cereals. Plant Pathol., 3:128129, 1954.

MALAVOLTA, E. Avaliação do estado nutricional das plantas: Princípios e aplicações. 2.ed. Piracicaba, Potafos, 1997. 319p.

MARTINEZ, H.E.P.; CARVALHO, J.G. \& SOUZA, R.B. Diagnose foliar. In: COMISSÃO DE FERTILIDADE DO SOLO DO ESTADO DE MINAS GERAIS. Recomendações para o uso de corretivos e fertilizantes em Minas Gerais - 5 a aproximação. Viçosa, MG, 1999. p.143-168.

MATUlA, J. \& PECHOVÁ, M. The influence of gypsum treatment on the acquirement of nutrients from soils by barley. Plant Soil Environ., 53:89-96, 2007.

MEDEIROS, J.C.; ALBUQUERQUE, J.A.; MAFRA, A.L.; DALLA ROSA, J. \& GATIBONI, L.C. Calcium:magnesium ratio in amendments of soil acidity: Nutrition and initial development of corn plants in a Humic Alic Cambisol. Semina Ci. Agrár., 29:799-806, 2008.

MELLO, I. \& RAIJ, B.van. No-till for sustainable agriculture in Brazil. In: WORLD ASSOCIATION OF SOIL AND WATER CONSERVATION PAPER, 2006, Washington. Proceedings... Washington, 2006. p.49-57.

PAVAN, M.A.; BINGHAM, F.T. \& PRATT, P.F. Redistribution of exchangeable calcium, magnesium and aluminum following lime or gypsum applications to a Brasilian Oxisol. Soil Sci. Soc. Am. J., 48:33-38, 1984.

PAVAN, M.A.; BLOCH, M.F.; ZEMPULSKI, H.C.; MIYAZAWA, M. \& ZOCOLER, D.C. Manual de análise química de solo e controle de qualidade. Londrina, IAPAR, 1992. 40p.

RAIJ, B.van; CANTARELLA, H.; QUAGGIO, J.A. \& FURLANI, A.M.C. Recomendações de adubação e calagem para o Estado de São Paulo. 2.ed. Campinas, IAC, 1996. 285p.

RAIJ, B.van; FURLANI, P.R.; QUAGGIO, J.A. \& PETTINELLI JR., A. Gesso na produção de cultivares de milho com tolerância diferencial a alumínio em três níveis de calagem. R. Bras. Ci. Solo, 22:101-108, 1998.

RAIJ, B.van. Gesso na agricultura. Campinas, Instituto Agronômico, 2008. 233p.

RAMOS, L.A.; NOLLA, A.; KORNDÖRFER, G.H.; PEREIRA, H.S. \& CAMARGO, M.S. Reatividade de corretivos de acidez e condicionadores de solo em colunas de lixiviação. R. Bras. Ci. Solo, 30:849 857, 2006. 
RAMPIM, L.; LANA, M.C.; FRANDOLOSO, J.F. \& FONTANIVA, S. Atributos químicos de solo e resposta do trigo e da soja ao gesso em sistema semeadura direta. R. Bras. Ci. Solo, 35:1687-1698, 2011.

RASHID, M.; IQBAL, M.N.; AKRAM, M.; ANSAR, M. \& HUSSAIN, R. Role of gypsum in wheat production in rainfed areas. Soil Environ., 27:166-170, 2008.

RIBAS, C. Caracterização da fertilidade atual dos solos de Guarapuava-PR. Guarapuava, Universidade Estadual do Centro-Oeste, 2010. 52p. (Dissertação de Mestrado)

RITCHIE, S.W.; HANWAY, J.J. \& BENSON, G.O. How a corn plant develops. Ames, Iowa State University of Science and Technology, 1993. 21p.

ROMEIRO, A.R. Meio ambiente e dinâmica de inovações na agricultura. São Paulo, Annablume, 1998. 277p.
SOUSA, D.M.G.; LOBATO, E. \& REIN, T.A. Uso de gesso agrícola nos solos do Cerrado. Planaltina, Embrapa Cerrados, 2005. 19p.

WAGNER, M.W.; JADOSKI, S.O.; SAITO, L.R.; SUCHORONCZEK, A. \& SCABENI, C.J. Comportamento de características climáticas para o manejo de culturas agrícolas em Guarapuava, centrosul do estado do Paraná. Pesq. Aplic. Agrotec., 2:41-49, 2009 .

VITTI, G.C. \& SUZUKI, J.A. A determinação do enxofre sulfato pelo método turbidimétrico. Jaboticabal, Universidade Estadual de São Paulo, 1978. 13p.

ZAMBROSI, F.C.B.; ALLEONI, L.R.F. \& CAIRES, E.F. Aplicação de gesso agrícola e especiação iônica da solução de um Latossolo sob sistema plantio direto. Ci. Rural, 37:110-117, 2007. 